Hur-var-närpolis. En granskning av närpolisreformen. BRA-rapport 2001-5. Brottsförebyggande rådet, Stockholm. 48 sider. ISBN 91-38-31774-5.

Brottsförebyggande rådet (BR $\AA$ ) fik i 1999 af den svenske regering til opgave at undersøge og evaluere nærpolitireformen i Sverige, og resultatet foreligger nu i en rapport forfattet af Peter Lindström, Anna Pauloff og Sven Granath. I lyset af det meget omfattende emne virker rapportens omfang (i alt 48 sider inklusive engelsksproget sammenfatning) meget begrænset, og efter endt læsning finder jeg, at undersøgelsen lader en del tilbage at ønske.

Rapporten indledes med en sammenfatning af de vigtigste resultater, hvorefter begrebet nærpoliti søges defineret, primært på baggrund af Rikspolisstyrelsens retningslinjer.

På de følgende sider beskrives BRÅ's opgave, som den blev stillet af regeringen, samt de centrale spørgsmål, som vil blive belyst i rapporten: 1) i hvilken udstrækning, intentionerne med nærpolitireformen er opnået, 2) hvorvidt politiets tilgængelighed og service har ændret sig, 3) i hvilket omfang, nærpolitiet arbejder problemorienteret, 4) hvorvidt reformen har påvirket opklaringsarbejdet i forhold til hverdagskriminalitet. Her må man som læser undre sig over, at spørgsmålet om forebyggelse af kriminalitet er helt fraværende, al den stund at netop forebyggelse af hverdagskriminalitet tidligere er beskrevet som et væsentligt mål for reformen, ligesom det er en væsentlig del af nærpolitiets arbejdsfelt $\mathrm{i}$ andre lande. Det er ikke ganske klart, om opgaven er stillet på en måde, så dette spørgsmål ikke specifikt fremgår, men forebyggelsesaspektet burde dog under alle omstændigheder være centralt for undersøgelsen: $E r$ der sket en ændring fra reaktivt, hændelsesstyret politiarbejde i retning af en øget præventiv indsats? Og i bekræftende fald: Har ændringen haft nogen effekt på kriminalitetsudviklingen og/eller på borgernes tryghed? Disse spørgsmål berøres overhovedet ikke i rapporten.

Det er tillige svært se, hvordan undersøgelsen er foregået i praksis. Det anføres, at der i 1999 gennemførtes en undersøgelse af 350 nærpolitifolk i Skåne, og i 2000 af nærpolitiet i Blekinge og Gotland og et politidistrikt i Stockholm, men rapporten meddeler intet om omfanget af undersøgelserne eller de metoder, som har været anvendt. Lidt mere udførlig omtale făr tre spørgeskemaundersøgelser, udsendt til alle nærpolitichefer i Sverige, om end de anvendte spørgeskemaer ikke specificeres. Endelig fremgår det, at der er anvendt diverse statistiske oplysninger, samt en række telefoninterviews med diverse "personer med god insyn i närpolisverksamheten vid landets samtliga polismyndigheter" (s. 14). Hvor mange interviews, der er foretaget, og hvorvidt der er tale om personer i eller uden for politiets egne rækker, fremgår ikke. Generelt er det ganske vanskeligt for læseren at bedømme baggrunden for undersøgelsens resultater.

På de følgende sider gennemgås de politiske og økonomiske forudsætninger for reformen, hvorefter udvikling og implementering beskrives. Heraf fremgår det, at reformen for mange politifolk stort set har bestået i en navneændring, idet mange forskellige politifunktioner ses at indgå i antallet af nærpolitifolk, med det resultat, at knap $40 \%$ af alle svenske politifolk i år 2000 betegnedes som nærpolitifolk. Rapporten foreslår derfor, at man i stedet ser på antallet af "allpoliser", politifolk som ikke har specialopgaver, og når frem til et tal på omkring $20 \%$ af alle politifolk. Her fremgår det tillige, at hovedparten af nærpolitifolkene arbejder i dagtimerne.

Med hensyn til service og tilgængelighed anfører rapporten, at disse aspekter er svært målbare pga. manglende data fra før reformens indførelse. Forholdene søges derpå vurderet gennem en optælling af antallet af politistationer og deres åbningstid (herunder om der er åbent uden for normal arbejdstid) samt en rundringning til 75 tilfældige nærpolitistationer for at undersøge, hvem der besvarer opkaldet, samt reaktionstiden. Disse oplysninger giver næppe noget udtømmende billede af politiets tilgængelighed, men afsnittet slutter med en anbefaling af, at flere nærpolitistationer holder åbent $\mathrm{i}$ weekenderne for dermed at styrke 
politiets mulighed for at yde service. Denne anbefaling belægges ikke med nogen yderligere argumentation og støttes ikke af erfaringerne fra de (få) konkrete nærpolitiområder i Sverige, jeg har kendskab til.

BRA's vurdering af omfanget af problemorienteret politiarbejde synes primært at bygge på nærpolitichefernes egne oplysninger i de tre enqueteundersøgelser, og nogen nærmere efterprøvning af oplysningernes overensstemmelse med faktiske forhold er tilsyneladende ikke sket. Det anføres, at eksistensen af lokale forebyggelsesråd har en positiv indvirkning på bredden i (men ikke antallet af) nærpolitiets samarbejdspartnere. Sådanne råd synes at kunne skabe kontakt til aktører, politiet hidtil ikke har været i kontakt med. Det er dog igen vanskeligt at vurdere denne konklusion, i og med at der ikke angives detaljerede oplysninger om besvarelserne og deres indhold. Det fremgår heller ikke, om forfatterne har interviewet medlemmer af sådanne forebyggelsesråd.

Den sidste fjerdedel af rapporten omhandler spørgsmålet om, hvorvidt nærpolitireformen har påvirket opklaringsarbejdet og sagsbehandlingstiden. Her konkluderes det, at sagsbehandlingstiden er blevet længere, men at dette ikke alene kan tilskrives reformen, men også andre ændringer. Det konkluderes også, at "reformen innebär att fler brott klaras upp" (s. 35). Denne konklusion bygger ikke på sammenligninger af data for de enkelte nærpolitiområder (fx før og efter reformen, eller i forhold til hinanden), da sådanne data angiveligt ikke findes (s. 35), men derimod på en sammenligning af Sveriges 21 länspolis-distrikter. Der er foretaget en vurdering af, hvor stor en del af det enkelte distrikts samlede efterforskningsarbejde, som ligger i nærpolitiregi, og distrikterne er så blevet inddelt i 3 grupper: distrikter med hhv. en høj, en lav og en varierende andel af efterforskning i nærpolitiregi. Herefter er udviklingen i antallet af opklarede sager vurderet for perioden 1995-98. Det viser sig her, at for distrikter med en høj andel af efterforskning i nærpolitiregi, er antallet af opklarede "vardagsbrott" steget med $18 \%$ i perioden, for distrikter med en varierende andel af efterforskningen henlagt til nærpolitiet er stigningen $11 \%$, og for de resterende distrikter er stigningen $8 \%$. Det forekommer af flere grunde betænkeligt at konkludere, som der gøres her. For det første er der tale om stigninger i absolutte tal, men der gives ingen oplysninger om udviklingen i anmeldelsestallet i de 21 distrikter i perioden. Der kan her være væsentlige forskelle distrikterne imellem, som kan influere på antallet af opklarede forbrydelser. For det andet siges der intet om en eventuel udvikling $\mathrm{i}$ borgernes tilbøjelighed til at foretage anmeldelse til politiet. Ændringer her vil også spille ind på antallet af opklaringer. For det tredje er andelen af efterforskning i nærpolitiregi primært vurderet ud fra forholdet mellem distriktets udgifter til efterforskningsarbejde i nærpolitiregi og de samlede udgifter til efterforskningsarbejde. En ændret fordeling af disse udgifter afspejler dog ikke nødvendigvis nogen ændring i politiets efterforskning i praksis; tidligere i rapporten (s. $19 \mathrm{ff}$.) diskuterer forfatterne selv spørgsmålet om, hvorvidt reformen i nogle distrikter alene har indebåret et navneskifte for personalet. Med disse forbehold in mente finder jeg ikke, at de påviste forskelle i antal opklarede lovovertrædelser udgør et overbevisende grundlag for forfatternes konklusion om reformens indflydelse på antallet af opklaringer.

Endelig må man vel sige, at mindre udsving i opklaringsprocenterne mellem de tre grupper af distrikter - uanset om der måtte være sammenhæng med reformen eller ej - er af forholdsvis begrænset betydning i forhold til nærpolitireformens samlede indvirkning på politiets arbejde med forebyggelse af hverdagskriminalitet og påvirkning af befolkningens tryghed og livskvalitet. Overvejelser af reformens virkning på disse områder er som nævnt helt fraværende i rapporten.

Generelt må det siges at være en meget begrænset evaluering, BR $\AA$ har foretaget. Den bygger primært på oplysninger fra politiet selv, og der er tilsyneladende ikke gjort noget forsøg på at efterprøve disse oplysninger empirisk. Læseren bliver ikke meget klogere på, hvad 
reformen faktisk har betydet for svensk politiarbejde. I den indledende sammenfatning konkluderes det, at "i diskussioner om reformen har mycket kommit att handla om organisatoriska förändringar" (s. 9). Det samme gælder desværre den foreliggende undersøgelse.

\section{Lars Holmberg}

Københavns Universitet

Beth Grothe Nielsen: Straffesystemet i børneperspektiv - seksuelle overgreb mod børn i familien. Jurist- og Økonomforbundets Forlag, 2001.

I 1994 startet jeg arbeidet med min doktoravhandling om hvordan rettsapparatet behandler saker om seksuelle overgrep mot barn. Gjennomgang av litteraturen på feltet viste at en dansk bok var særskilt relevant for mitt prosjekt. Denne boken var Beth Grothe Nielsens "Seksuelle overgreb mod børn i familien: et offerperspektiv på straffesystemet" (Aarhus Universitetsforlag 1991). Det skulle imidlertid vise seg å være vanskelig å fremskaffe den boken var utsolgt fra forlaget. At den var utsolgt var ikke overraskende tatt $\mathrm{i}$ betraktning av at boken var enestående på feltet både innenfor og utenfor Nordens grenser.

I 2001 kom Beth Grothe Nielsen med en ny, revidert utgave av denne boken. Bokens nye tittel, Straffesystemet i børneperspektiv - seksuelle overgreb mod børn i familien, understreker bokens fokus - hvordan straffesystemet virker sett fra barnets synsvinkel. I denne utgaven har Nielsen foretatt en gjennomgripende revisjon, ajourføring og utvidelse på bakgrunn av den omfattende faglige produksjonen og utviklingen som har funnet sted på feltet seksuelle overgrep mot barn siden førsteutgaven kom ut. Foruten en oppdatering av materialet fra den første boken, presenterer Nielsen nye og spennende perspektiver og synspunkter på hvordan saker om seksuelle overgrep mot barn i familien kan ivaretas på en bedre måte $\mathrm{i}$ fremtiden.

I boken redegjør Nielsen for hva som skjer med saker om seksuelle overgrep mot barn gjennom rettsprosessen. Nærmere bestemt følger hun saken fra politianmeldelse til saken henlegges eller går videre til rettsbehandling og dom. Nielsen belyser prosessen ved å redegjøre for de rettslige og prosessuelle reglene som kommer til anvendelse gjennom rettsprosessen. I fremstillingen trekker Nielsen inn et bredt tilfang av kilder, hvorav den sentrale faglitteraturen på feltet står sentralt, samt muntlige utsagn om prosessen fra fagfolk på feltet og ikke minst fra jenter som selv har opplevd seksuelle overgrep og en strafferettslig behandling av saken. Nielsen redegjør også for de ulike fasene i rettsprosessen ved bruk av rettspraksis. Hennes materiale omfatter utskrifter av doms- og rettsbøker, samt politidokumenter i henlagte saker. Dommene er avsagt i perioden 1983-1990, mens de henlagte sakene er knyttet til året 1988. Materialet omfatter 91 dommer om seksuelle overgrep i foreldrebarn relasjoner, mens 88 omfatter slike overgrep i steforeldre-barnrelasjoner. I tillegg omfattes 45 henlagte saker. I den ajourførte utgaven er materialet supplert med avgjørelser fra 1990-årene og hvor systematisk innsamlet materiale er hentet fra 1997 og 1998.

I følge Nielsen er ikke rettsapparatet blitt bedre egnet til å behandle saker om seksuelle overgrep mot barn siden hun utga boken første gang. Vi må tenke nytt sier Nielsen - og uttrykker behov for et paradigmeskifte i behandlingen av saker om seksuelle overgrep mot barn. På dette punkt bringer Nielsen inn nye problemstillinger og perspektiver sett $\mathrm{i}$ forhold til sin første bok. Der hun tidligere stilte spørsmålet om hvordan rettsapparatet kan gjøres bedre egnet til å behandle saker om seksuelle overgrep mot barn - spør hun om det er andre måter å ivareta disse sakene på enn det den tradisjonelle rettspleien kan tilby.

I bokens kapittel 1 gis en historisk fremstilling av begrepene incest/blodskam. I dette kapittelet problematiserer også Grothe Nielsen bruken av vide og snevre definisjoner av 
begrepene. Hun viser hvordan valg av definisjoner i mange tilfeller avspeiler forfatterens tilnærming til temaet. For eksempel vil bruk av begrepet voldtekt om seksuelle overgrep mot barn avspeile at forfatteren finner slike overgrep svært grove, mens andre definisjoner kan bidra til å minimere grovheten i handlingene. Samtidig trekker Nielsen frem den kritikken som vanligvis forekommer ved bruk av snevre eller vide definisjoner av seksuelle overgrep mot barn. Nielsen redegjør også for feministisk litteratur som har kritisert en rekke myter på feltet, blant annet myter om at incest er et resultat av aksept av slike seksuelle handlinger innenfor subkulturer, eller oppfatningen innenfor psykiatrien hvor incestforbryteren blant annet sees som psykisk avvikende eller som "normal" med et stort seksuelt behov. I dette kapittelet foretar også Nielsen en gjennomgang av nasjonale og internasjonale omfangsundersøkelser av seksuelle overgrep mot barn og belyser striden om fenomenets omfang.

I kapittel 2 foretar Nielsen en rettshistorisk gjennomgang av reglene rundt incest. Nielsen redegjør for hvordan incest er blitt strafferettslig behandlet og begrunnet fra Moseloven og frem til dagens strafferettslige regulering. I dette kapittelet foretar Nielsen også en gjennomgang av rettspraksis knyttet til straffeutmåling i saker om seksuelle overgrep mot barn. Kapittelet omfatter også en rettsdogmatisk redegjørelse for sentrale begreper knyttet til seksuelle overgrep mot barn, vold og trusler, betydningen av alder, samtykke og medvirkning. Om den seksuelle handlingen har omfattet samleie eller annen kjønnslig omgang har betydning for hvilken straffebestemmelse som kommer til anvendelse. For barna har disse distinksjonene betydning fordi det innebærer at de under saken blir avhørt om de mest intime detaljer rundt overgrepshendelsen. Kapittelet omfatter også en redegjørelse for reglene rundt foreldelse.

I bokens kapittel 3 belyser Nielsen straffesystemet ut fra et offerperspektiv. Her beskriver Nielsen hvordan dommer og domsutskrifter er lite egnet til å belyse ofrenes situasjon. Viktig i denne sammenheng er hvordan ofrene ikke har en selvstendig rolle i rettsprosessen - men kun er "forbrydelsens genstand på samme måde som fx ting..." (2001 s. 64), og som Nielsen skriver - ofrenes sosiale og menneskelige fornedrelse beskrives heller ikke i domsreferatene. Feministisk orientert viktimologi har imidlertid belyst ofrenes maktesløse stilling i forhold til både gjerningsmannen og rettssystemet og Nielsen redegjør for denne litteraturen. Hun redegjør også for ofrenes prosessuelle stilling i rettsprosessen og hvordan rettssystemet er et system tilpasset voksne aktører. Nielsen trekker videre frem undersøkelser som viser at den strafferettslige behandlingen av saken kan være belastende for offeret. I dette kapittelet gjennomgår også Nielsen reglene knyttet til barnets deltakelse under straffesaken. Både før og nå er barn betraktet som utroverdige vitner i straffesaker generelt og i saker om seksuelle overgrep mot barn. Nielsen foretar i denne sammenheng en bred gjennomgang av forskningen rundt barns troverdighet i saker om seksuelle overgrep, samt den omfattende forskningen som foreligger rundt barns troverdighet som vitner.

I bokens kapittel 4 belyser Nielsen anmeldelsen og ikke minst hvilke forhold som forhindrer at saker om seksuelle overgrep mot barn kommer til rettsapparatets kunnskap. Her viser hun til undersøkelser som indikerer at kun en liten andel av seksuelle overgrep mot barn kommer til rettsapparatets kunnskap. På feltet seksuelle overgrep mot barn møter en ofte påstanden om at falske anmeldelser om seksuelle overgrep mot barn er utbredt. I denne forbindelse belyser hun tre situasjoner hvor det ofte hevdes at påstanden om seksuelle overgrep er falsk. Den første er saker hvor barnet mistenkes utsatt for seksuelle overgrep ut fra en rekke uspesifisierte symptomer og hvor psykologer beskyldes for å ha innfortolket en incestmistanke. Den andre er tilfeller hvor mor påstås å ha diktet opp en incestmistanke for å vinne omsorgen for barnet i en konflikt med barnets far. Den tredje er den hvor voksne kvinner mener å huske overgrep fra barndommen som de senere har fortrengt. Også i disse tilfellene 
beskyldes terapeuter for å medvirke til falske overgrepsanklager. I kapittelet belyses også sosiale myndigheters rolle i disse sakene, herunder en rekke sentrale problemstillinger knyttet til taushets- underretnings- og opplysningsplikt. Gjennom eksempler redegjør hun også for hvordan sakene kommer til rettsapparatets kunnskap.

Bokens femte kapittel omhandler politiets etterforskning av sakene. Her redegjør Nielsen for bistandsadvokatordningen, avhør av fornærmede og siktede, av andre vitner og for tekniske bevis. Stor vekt legges selvsagt på fornærmedes forklaring hvor en får innsikt både i hvordan selve avhøret rent praktisk gjennomføres, for eksempel adgangen til bruk av tekniske hjelpemidler. Nielsen illustrerer også gjennom eksempler hvilken form og innhold avhøringen har hatt og endringer som har funnet sted over tid. I redegiørelsen for siktedes forklaring får en innblikk i hvordan siktede møter påstanden om å ha begått seksuelle overgrep. Hun viser blant annet at siktede ofte fraskriver seg ansvaret for handlingene i de tilfellene hvor de innrømmer å ha begått seksuelle overgrep. Nielsen redegjør også for rettsmedisinsk undersøkelse av fornærmede og psykologiske og psykiatriske undersøkelser.

I kapittel 6 belyser Nielsen påtalemyndighetens (anklagemyndighetens) avgjørelse av om det skal tas ut tiltale. Hun redegjør i denne forbindelse for hva som kjennetegnet de sakene som endte med henleggelse i hennes materiale. At forholdet ligger tilbake i tid, barnets unge alder, at barnet har et handicap, samt konflikt mellom foreldrene er forhold som kan synes å trekke i retning av henleggelse. Nielsen illustrerer også gjennom eksempler hvilke konsekvenser en henleggelse kan ha for offeret. Når det gjelder sakene hvor det tas ut tiltale skiller ikke disse sakene seg på en klar og tydelig måte fra sakene som endte med henleggelse.

Domstolsbehandlingen belyses i bokens kapittel 7. Nielsen redegjør her for sentrale prosessuelle prinsipper og prosessuelle regler og făr frem hvilken betydning disse har i saker om seksuelle overgrep mot barn. I denne forbindelse kan det nevnes at fornærmedes stilling under straffesaker er under diskusjon i Norge. Dr. juris Anne Robberstad har på oppdrag fra Justisdepartementet foretatt en gjennomgang av fornærmedes stilling i straffesaker i norsk og internasjonal rett (Anne Robberstad: "Fra kontradiksjon til verdighet. Komparativ fremstilling av fornærmedes stilling i de nordiske land." Universitetet i Oslo 2002). Robberstad foreslår å styrke fornærmedes stilling blant annet ved at fornærmede bør få selvstendige partsrettigheter under straffesaken. En styrket stilling under saken kan være med å gi fornærmede en opplevelse av å få en mer verdig behandling under saken. Presseoppslag i etterkant av høringsrunden tyder på at forslagene møter sterk motbør særlig fra påtalemyndighet og domstoler.

Jeg vil spesielt fremheve bokens kapittel 8. Dette kapittelet er nytt i forhold til førsteutgaven. Her får Nielsen tydelig frem hva det vil si å være barn i strafferettsapparatet i saker om seksuelle overgrep mot barn. Gjennom historier fra sakene får hun frem hvordan saken kan oppleves fra barnets ståsted. Nielsen får videre frem hvordan den rettslige behandlingen belaster relasjonene og setter barnet i en svært vanskelig situasjon. Hun viser også hvordan straffesystemet fremmer benektelse og ikke erkjennelse hos tiltalte. Trusselen om straffesak er også til hinder for at overgrep avsløres. Dette er særlig viktig i forhold til forebygging av overgrep.

Nielsen belyser videre medias rolle i saker om seksuelle overgrep mot barn. Hun gir en detaljert beskrivelse av medias dekning av den såkalte "Roum-saken". Fremstillingen viser hvordan saken vekket sterke følelser og førte til en polarisert debatt. Hun får også frem hvilke omkostninger en slik sak kan ha for fagfolk som involveres i slike saker og ikke minst for barna som saken gjaldt. I Norge hadde vi en lignende sak - den såkalte Bjugn-saken. Debatten i Danmark har klare likhetstrekk med den norske debatten som fant sted i kjølvannet av Bjugn-saken. Nielsen beskriver også hvor risikabelt det kan være å arbeide på feltet og hvor 
resultatet kan bli angrep mot faglig og personlig integritet. Slike erfaringer er dessverre ikke ukjente - men finnes igjen også hos andre fagpersoner som har gjort nybrottsarbeide på feltet. Nielsen reiser spørsmål om man ti år etter at boken ble utgitt første gang kan ha en saklig debatt om seksuelle overgrep mot barn eller om temaet fortsatt er like provoserende og preget av tabuisering slik at debatten vil preges av personangrep.

Nielsen belyser også hvordan den strafferettslige behandlingen kan få konsekvenser utover sitt virkeområde - blant annet for sosiale myndigheters arbeide. Den rettslige behandlingen "tvinger" fokus mot bevis for og imot overgrepsmistanken. A vinne eller tape saken blir det sentrale. Samtidig fører denne fokuseringen til at overgrepsmistanken overskygger andre problemer barna sliter med. Dette gir et dårlig grunnlag for sosiale instansers videre arbeid med saken. På denne måten fører den strafferettslige fokuseringen til at sosiale myndigheter settes ut av spill. Nielsen tar også for seg samarbeid mellom ulike instanser i saker om seksuelle overgrep mot barn. I denne forbindelse trekker hun frem den såkalte Cleveland-saken hvor manglende samarbeid var et sentralt problem. Følgen ble at man mistet barnas interesser av syne. Nielsen reiser i denne forbindelse problemstillingen om i hvilken grad ulike samarbeidsmodeller er egnet til å ivareta barnets interesser. Så lenge strafferettens "mandat" opprettholdes, vil strafferettens syn prege samarbeidet i tverrfaglige samarbeidsmodeller hevder Nielsen.

Nielsen er kritisk til hvor egnet straffesystemet er til å beskytte barn mot seksuelle overgrep. Når en tar barnets perspektiv blir rettssikkerhet og beskyttelse fraværende. Hun presenterer imidlertid spennende perspektiver i forhold til nye måter samfunnet kan håndtere saker om seksuelle overgrep mot barn. I denne forbindelse trekker hun frem alternative konfliktløsningsmodeller eller "restorative justice". Hun fremstiller en kanadisk konfliktløsningsmodell og stiller denne opp mot den tradisjonelle domstolsbehandlingen. Den kanadiske modellen gir i følge Nielsen mulighet for en mer helhetlig tilnærming enn den tradisjonelle rettsbehandlingen blant annet fordi den ikke skreller bort følelsene hos de involverte som irrelevante slik rettsbehandlingen vanligvis gjør. Den kanadiske modellen innebærer videre en kollektiv tilnærming til overgrepsproblematikken ved at en rekke personer involveres og den er egnet til å ansvarliggjøre gjerningspersonen. Denne modellen fokuserer videre ikke bare på det som har skjedd, men retter også blikket fremover i tid. På dette punkt skiller den seg vesentlig fra den tradisjonelle rettsbehandlingen som i stor grad retter blikket bakover i tid.

Med denne boken presenterer Nielsen et viktig bidrag av nasjonal og internasjonal betydning i debatten om hvordan barn i saker om seksuelle overgrep mot barn best kan ivaretas. Gjennom bruk av eksempler gjennom hele boken skaper Nielsen nærhet til de hun ønsker å rette fokus mot i denne boken - barna. Nielsen presenterer perspektiver og refleksjoner som vil være viktige premisser for å lede debatten om seksuelle overgrep mot barn inn på nye veier. Dette innebærer å lede debatten ut av den tradisjonelle tenkningen hvor rettssystemet står i fokus og over på alternative måter å behandle seksuelle overgrep mot barn på. Boken anbefales på det sterkeste til alle som arbeider med seksuelle overgrep mot barn både praktikere og forskere på feltet. Særlig bør boken leses av ansatte innen politi og rettsvesen, herunder politifolk, representanter fra påtalemyndigheten, advokater og dommere. Skaff boken - før den blir utsolgt fra forlaget!

\section{Elisiv Bakketeig}

Justisdepartementet i Norge 